\title{
Taxpayer Awareness and Understanding on Taxpayer Compliance in Nepal
}

\begin{abstract}
Naba Raj Adhikari*
Abstract

This study aims at examining the influence of taxpayer awareness and taxpayer understanding toward taxpayers' compliance in Nepal. The research population is taxpayers that are registered in Inland Revenue Office, Nepalgunj. This study used convenience as well as purposive sampling as a sampling technique. A total number of 60 questionnaires were distributed to the taxpayers comprised with five point Likert scale with 1 for a highly disagreeable rate to 5 for a strongly agreed answer from Nepalgunj sub metropolitan during January to March 2020 AD. Out of these, 52 questionnaires were returned and accepted for data analysis. Descriptive statistical analysis and linear regression analysis have been applied as for the analysis of data. The findings of this study showed that the taxpayer awareness and understanding of tax have a positive and significant effect on taxpayer compliance. The taxpayer understanding have a stronger influence than a variable of taxpayer awareness. Therefore it is suggested that the tax office should enforce tax education programs to taxpayers regularly and continuously to increase the taxpayers' understanding and awareness.
\end{abstract}

Keywords: Taxpayer awareness; taxpayer understanding; taxpayer compliance

\section{Introduction}

Tax has become a major player in every society of the world Azubike (2009). The tax system is an opportunity for government to collect additional revenue needed in discharging its pressing obligations. Nzotta (2007) explained four key issues to be understood for taxation to play its functions in the society and taxation has been regarded as a compulsory contribution made by the citizens to the government and for the general common use, imposes a general obligation on the tax payer, presumption that the contribution to the public revenue made by the tax payer may not be equivalent to the benefits received and not imposed on a citizen by the government because it has rendered specific services to him or his family. The role of taxpayer awareness and understanding in taxpayers' compliance has become crucial for a nation in an effort to collect the state revenue from tax sector (Rahayu et al., 2017). Tax compliance has been viewed a significant issue for many tax authorities and it has not considered easy task to persuade taxpayers to comply with tax requirements even though tax laws are not always precise (James \& Alley, 2002).

* Associate Professor, Central Department of Management, Tribhuvan University, Kathmandu, NEPAL Email id:adhikarinavaraj7@gmail.com 
Tax compliance is defined as the full payment of all taxes due (Braithwaite, 2009). However tax non-compliance is referred to as any difference between the actual amount of taxes paid and the amount of taxes due. According to Ayuba, et al., (2016) tax compliance regarded as taxpayers adhere to relevant tax laws and regulations. However Marziana,et al., (2010) highlighted the tax compliance as the degree to which taxpayer adhere with tax laws and regulations in their own country. In general ethical persons are more tax compliant than unethical persons (Ambala, 2015). Furthermore taxpayers' attitude has been identified as crucial one factor that play important role in influencing tax compliance behavior and the compliances influenced by both attitudinal and psychological factors (Jayawardane, 2015). Troiano, (2017) mentioned that the sharing of tax information across governments has been found to improve compliance. The tax rate, withholding position and individual ethical orientation can influence a tax-payers compliance behavior. Moreover tax compliance leads to increases in income and audit rates and decreases in tax rates. Compliance has been greater when the individuals perceive some benefits from a public good funded by the tax payments while changes in fine rates appear to have little effect on tax compliance behavior (Alm et al., 1992). Garboua, (2006) explored that fairness is the most important issue rather than tax burden, tax rate and efficiency of government expenditures. Similarly a high level of fairness leads to a high level of tax compliance.

Rahayu et al. (2017) identified that knowledge and understanding of tax regulation and awareness of taxpayers simultaneously contribute to taxpayer compliance. Mehari, et al., (2017) revealed that procedures of tax collection and enforcement of the tax law influence positively the voluntary tax compliance behavior of taxpayers. In addition to tax education, knowledge about tax laws also plays a major role in determining taxpayers' compliance behavior (Carroll \& Goodman, 2011). Taxpayer awareness is an effort or action accompanied by self-encouragement and willingness to perform the rights and obligations of taxation in accordance with the regulations. Munari (2005) also explained that taxpayers experience awareness when they know the existence of laws and provisions of taxation; know the function of paying taxes to the state; understand the rights and obligations to be implemented; count, pay and report voluntarily; calculate, pay and report taxes correctly. Furthermore, it proves the awareness of taxpayers in making tax payments and reports has demonstrated the formal compliance that is, making tax payments and reports right on time. The indicators of taxpayer awareness are measured by knowing tax functions, understanding taxpayers' rights and obligations, being able to calculate taxes, being able to pay taxes, and being able to report taxes. Understanding taxpayers for taxation regulations is a way for taxpayers to understand existing taxation regulations. Santoso (2008) argued that the knowledge or understanding of taxpayers on tax regulation can also affect the obedience of the taxpayer itself and the more people understand the tax laws, the higher the state revenue obtained from the tax sector because the public realizes the importance of taxes to the state. Furthermore the understanding also makes the taxpayer understand the rights, obligations and sanctions including the tax of private entrepreneurship (Akintoye \& Tashie, 2013). Beesoon, (2016) found that tax knowledge and education has a negative and significant impact on tax compliance. In order to increase level of tax compliance, Richardson, (2006), and Kirchler et al., (2008), believed 
that tax knowledge plays the important role. Hence, people should be equipped with the tax education so that everyone has a sufficient knowledge towards competent taxpayers. Park \& Hyun (2003), suggested that tax education is one of the effective tools to induce taxpayers to comply more. On the other hand, if the taxpayers well understand basic concept of taxation leads to willing to comply (Marziana et. al., 2010). Bernadette, et al., (2012) concluded on the lack of knowledge and understanding of taxation by small business owners who are less likely to comply with the tax payment. Ali, et al., (2014) agreed that there is an influence of tax knowledge and understanding on the compliance in carrying out tax obligations. Compliance to taxation policies has been a challenge among developing and developed countries around the globe (Charlet \& Owens, 2010). Furthermore the developing countries are still featuring a low level of tax compliance due to the many obstacles prevailing for voluntary tax compliance (Alabede, et al., 2011). In this context the study aims:

- To examine the relationship between the taxpayer awareness and taxpayer understanding toward taxpayers' compliance in Nepal.

- To analyze the impact of the taxpayer awareness and taxpayer understanding toward taxpayers' compliance.

\section{Methodology}

This study has followed descriptive and explanatory research design. The taxpayers that are registered in Inland Revenue Office, Nepalgunj are the population of this study. This study have used survey method using convenience and purposive sampling technique to collect primary data from the respondents having knowledge and understanding of tax regulations, taxpayer awareness, as well as taxpayer compliance given to respondents as compulsory taxes comprised with five point Likert scale with 1 for a highly disagreeable rate to 5 for a strongly agreed answer. A total number of 60 questionnaires were distributed to the taxpayers from Nepalgunj sub metropolitan during January to March 2020 AD. Of these, 52 questionnaires were returned and accepted for data analysis. Descriptive as well as inferential statistics have been applied for the analysis of relevant information. To identify the linear relationship between tax payers' compliance and taxpayer awareness and understanding a linear regression model has been applied having dependent and independent variables. The regression model is represented as follows:

Tax_ $C=\beta_{0}+\beta_{1 \mathrm{AW}}+\beta_{2 \mathrm{UD}} \ldots+$ et

Where: Tax_ $\mathrm{C}=$ Taxpayer Compliance, $\mathrm{AW}=$ Awareness, $\mathrm{UD}=$ Understanding and et $=$ error term

\section{Results and discussion}

Table 1 Descriptive analysis of the variables

\begin{tabular}{lrrr}
\hline & Awareness & Understanding & Taxpayer compliance \\
\hline Mean & 3.235 & 4.1412 & 3.5235 \\
Std. Deviation & .56285 & .62853 & .47130 \\
Level & Moderate & High & Moderate \\
\hline
\end{tabular}

Field survey 2020 
Table 1 presents the mean value and standard deviation of awareness, understanding and taxpayers' compliance. The mean value (4.1412) of understanding highlights that the taxpayers have high level (more than 4.00 mean value) of knowledge and understanding on tax rules and regulations. While the awareness revealed in moderate level having less than 4.00 mean value. It indicates that the taxpayers have moderate level of awareness in existence of laws and provisions of taxation; tax functions and understanding taxpayers' rights and obligations. Likewise taxpayer compliance also reflects in moderate level.

Table 2 Relationship between awareness and taxpayer compliance

\begin{tabular}{lll}
\hline & Taxpayer compliance $(\mathrm{r})$ & Sig. \\
\hline Awareness & .261 & 0.032 \\
\hline
\end{tabular}

Field survey 2020

Table 2 highlights the association between awareness and taxpayer compliance. The result $(r=.261)$ at 95 percent level of confidence reveals the low degree of positive relationship between awareness and taxpayer compliance due to moderate level of taxpayer awareness.

Table 3 Relationship between understanding and taxpayer compliance

\begin{tabular}{lll}
\hline & Taxpayer compliance $(r)$ & Sig. \\
Understanding & .488 & 0.013 \\
\hline
\end{tabular}

Field survey 2020

Table 3 presents the association between understanding and taxpayer compliance. The coefficient value $(r=.488)$ at 95 percent level of confidence indicates moderate positive relationship between awareness and taxpayer compliance due to high level of taxpayer understanding on tax rules and regulations.

Table 4 Effect in relationship of awareness and understanding on tax compliance

\begin{tabular}{lcc}
\hline Model & Coefficient & Sig. \\
\hline (Constant) & 2.097 & .000 \\
Awareness & .125 & .033 \\
Understanding & .239 & .000 \\
F & 13.256 & .000 \\
R Square & & \\
\hline
\end{tabular}

Dependent Variable: Taxpayer compliance

Field survey 2020

Regression equation: Tax_C $=4.097+.125_{\mathrm{AW}}+.239_{\mathrm{UD}} \ldots+\mathrm{et}$ 
According to the table 4 taxpayer compliance has been explained by thirty nine percentage $(\mathrm{R}$ Square $=.39)$ from the given variables taxpayer awareness and taxpayer understanding. Furthermore the $\beta 1$ and $\beta 2$ coefficients .125 and .239 indicates the positive impacts of taxpayer awareness and taxpayer understanding on taxpayer compliance at 95 percent level of confidence. Due to the high level of taxpayer understanding it revealed high level of impact on taxpayer compliance than taxpayer awareness.

\section{Conclusion}

The study basically aims to examine the influence of tax awareness and tax understanding toward taxpayers' compliance in Nepal. Based on the findings in this study, the conclusion that can be drawn is the understanding of taxation and awareness of taxpayers have a positive and significant impact on taxpayer compliance in Nepalgunj sub metropolitan which is in the line of Rahayu et al. (2017) but it differs from the line of Beesoon, (2016). Tax understanding have more dominant influence than the awareness on taxpayers' compliance. In this regard it is suggested that the tax office should enforce tax education programs to taxpayers regularly and continuously to increase the taxpayers' understanding and awareness. Furthermore this study can be used for further research regarding cross district as well as cross country comparisons.

\section{References}

Alabede, J. O., Zaimah, Z. A., \& Kamil, M. I. (2011). Determinants of tax compliance behavior: An alternative model for Nigeria. International Research Journal of Finance and Economics, 78, 121-136.

Alm, J., Jackson, B. R. \& Mckee, M. (1992). Estimating the determinants of taxpayer compliance with experimental data. National Tax Journal, 65(1), 107-114.

Ali,M., Fjeldstad, O. \& Sjursen, I. H. (2014). To pay or not to pay? Citizens' attitudes toward taxation in Kenya, Tanzania, Uganda, and South Africa. World Development, 64 (December), 828-842.

Ambala, R.N. (2015). Influence of individual ethical orientation on tax compliance: evidence among Ghanaian taxpayers. Journal of Accounting and Taxation, 7(6), 98-105.

Akintoye, I.R \& Tashie, G.A. (2013). The effect of tax compliance on economic growth and development in Nigeria. British Journal of Arts and Social Sciences, 11(2), 222-231.

Ayuba, A., Saad, N., \& Ariffin, Z. Z. (2016). Does perceived corruption moderate the relationship between economic factors and tax compliance marginally? A newly developed model for Nigerian Small and Medium Enterprises. Mediterranean Journal of Social Sciences, 7(1), 402-409.

Azubike, J.U.B. (2009). Challenges of tax authorities, tax payers in the management of tax reform processes. Nigeria Account, 42, 36-42.

Beesoon, D., Hemavadi, S., \& Jugurnath, B. (2016). Assessing the determinants of income tax compliance in Mauritius: A study of individual taxpayers. Proceedings of the Fifth Asia Pacific Conference on Global Business, Economics, Finance, Ebene, Mauritius, 1-33. 
Bernadette, K., Korunka, C. \& Kirchler, E. (2012). Tax compliance of small business owners. International Journal of Entrepreneurial Behaviour \& Research, 18 (3), 330-351.

Braithwaite, V. (2009). Defiance in taxation and governance. Resisting and Dismissing Authority in a Democracy, Edward Elgar, Cheltenham.

Carroll, D. A. \& Goodman, C. B. (2011). The effects of assessment quality on revenue volatility. Public Budgeting \& Finance, 31(1), 76-94.

Charlet, A., \& Owens J. (2010). An international perspective on VAT. Tax Notes International, 59(12), 943-954.

Garboua, L. L., Montmarquette, C., \& Masclet, D. (2006). A micro foundation for the Laffer curve in a real effort experiment, CIRANO working papers, 1-33.

James, S. \& Alley, C. (2002). Tax compliance, self-assessment and tax administration. Journal of Financial and Management in Public Services, 2(2), 27-42.

Jayawardane, D. (2015). Psychological factors affect tax compliance- A review paper. International Journal of Arts and Commerce, 4(6), 131-141.

Kirchler, E., Hoelzl, E., \& Wahl, I. (2008). Enforced versus voluntary tax compliance: the slippery slope framework. Journal of Economic Psychology 29(2), 210-225.

Marziana, H. M., Norhafizah, A., \& Mohamad, S. D. N. (2010). Perceptions of taxpayers with the level of compliance: A comparison in the East coast region, Malaysia. Journal of Global Business and Economics, 1(1), 241-257.

Mehari, D., Abdulmajeeb, \& Pasha. (2017). Factors affecting voluntary compliance of taxpayers: Attitude of Arbaminch, SNNPR, Ethiopia. International Journal of Scientific and Research Publications, 7(6), 48-63.

Munari, A. (2005). Influence success factors against tax payer acceptance of income tax (KPP Case Study Batu, Malang). Executive Journal. 2(2), 120-124.

Nzotta, S.M. (2007). Tax evasion problems in Nigeria: A critique. Nigeria Account, 40, 40-43.

Park, C.G., \& Hyun, J.K. (2003). Examining the determinants of tax compliance by experimental data: A case of Korea. Journal of Policy Modeling 25 (8), 673-684.

Rahayu, Y. N., Setiawan, M., Troena, E.A. \& Sudjatno (2017). The role of taxpayer awareness, tax regulation and understanding in taxpayer compliance. Journal of Accounting and Taxation, 9(10), 139-146.

Richardson, G. (2006). Determinants of Tax Evasion: A Cross Country Investigation. Journal of International Accounting, Auditing \& Taxation 15(2), 150-169.

Santoso, W. (2008). Failure risk analysis as the basis for increased taxpayer compliance. Journal of Accounting and Taxation, 5(1), 85-137.

Troiano, U. (2017). Do taxes increase economic inequality? A comparative study based on the state personal income tax. NBER Working Paper series, Working Paper 24175 National Bureau of Economic Research, 1050 Massachusetts Avenue Cambridge, MA 02138 December, 1-40. 